\title{
A Study on the Educational and Artistic Functions of Museums Based on Film and Television Works
}

\author{
Xintian Liu ${ }^{1}$ \\ ${ }^{1}$ Coll Visual \& Performing Arts, George Mason University, Fairfax, VA 22030, USA. \\ Email: 1219059486@qq.com
}

\begin{abstract}
With the development of society and economy, people have higher pursuit of spiritual life, and museums as a service-oriented public cultural activities are gradually accepted and recognized by the public. This paper relies on the narrative structure of the film, and takes Barnes Foundation as the background and finds out the new changes, new enjoyment and the significance of the changes to the life of the public.
\end{abstract}

Keywords : artistic work, Art Museum, Education, Appreciate

\section{INTRODUCTION}

The Art of stealing is a film made by Don Argot, a famous American documentary film director. The film tells the story of the Barnes Foundation's unfortunate fate. The doctor in the film, Albert Julian Barnes, was born into a working class family in Philadelphia, but he later made a fortune through his business, which was used to treat certain diseases. Julian Barnes was also passionate about art. He was an avid collector of unique post-impressionist and early modernist works. His Art collection is recognized as one of the most important and influential private collections, including 181 works by Renoir, 69 by Paul Cézanne, 59 by Mattis, 46 by Picasso, 21 by Sadin and 18 by Henri Rousseau, 16 for the Amedeo Modigliani, 11 for Degats, 7 for Van de Gard and 6 for Seurat. Even more unique is his fine collection of African Art. INCLUDING: Ancient Egyptian ancient master works of art and ancient Greek and Roman art, painting manuscripts, works of art and so on. His art collection is worth more than \$25 billion. But Julian Barnes's first exhibition of art was despised by Philadelphia's cultural luminaries, who called his collection "worthless and degenerate art. "[1] Similarly, Julian Barnes himself was ridiculed and ostracized by the local aristocracy. They saw Julian Barnes as the antithesis of the Philadelphia Art World. But Julian Barnes didn't give up. He continued to keep his collection and built a mansion for his art at Merrion. He used the building for education, but it was closed to the public and was not a public museum. Since Julian Barnes had never had children in his life, he feared that his art collection would not survive or be damaged after his death. So Julian Barnes made a will, and when he died, he donated all of his art collection to the foundation. All of the foundation's art collections can't be lent, sold or moved, and they must be protected ${ }^{[2]}$.

As it turned out, Julian Barnes's fears were real. The foundation has changed dramatically since the last guardian of Julian Barnes's will died in 1988. The Barnes Foundation's control of the art collection was transferred to Lincoln. The principal, Granton, used the art collection to make money, so he broke Julian Barnes's will, using many of the paintings to travel to the public to make money, and even selling some of them. The film centers on the conflicted relationship between Julian Barnes and the Philadelphia Aristocracy, and society at large. The Barnes Foundation was set up to improve and develop "education and the appreciation of fine arts and horticulture" , in keeping with Julian Barnes's original intention of expanding the scope of education to a variety of art education courses. On the contrary, the Public Exhibition of Julian Barnes's works of art gives all those who have a passion for art, such as Julian Barnes, the opportunity to appreciate the works of the masters, ordinary people can also appreciate the aesthetics of a work of art. People are grateful to Julian Barnes for collecting and preserving these works ${ }^{[3]}$.

In the film, the arts get too many attentions from local bigwigs and cultural elites. They try to shape the arts to some kinds of sale advantage, and government ignores these national soft powers by offering a little funding. Local power holders need to protect cultural industries as assets, so they lock up art in their control, 
or offer a highly cost on artistic culture. At the time the society, Barnes Foundation is steadily grown to cover the demand of cultural elites and local bigwigs to earn money and resources from the new-style cultures. Government supports them that allowing the expand of protecting copyright under their wings. However, all of these are looking for matching the demands of society for greater earnings and stock performance, but not struggle for public's interest in the arts. In that time, people may consider creative activity as a positive force rather than connect with $\operatorname{art}^{[4]}$.

The bifurcation about cultural classes changes audience's attitude from active involvement to remain quiet and controlled. As that century wore on, the cultural class became more strictly clear and definite, and can hardly be tolerant to equally treat high culture and popular entertainment. ${ }^{[5]}$ It preferred to think about whose identity has qualifications should visit museums or go to theater to do some artistic activities rather than the purpose of the culture with its function and how the culture could be used to improve people's life. People who considered they had good educated and cultured could attend the event which is kind of elegant, serious artistic activity, while the others went to popular form of entertainment which even cannot connect with art. People should consider that the culture can be obtained for every group, which means it is kinds of values or practical conditions that people used to interact with environment; or the culture is a kind of private property owned by few people who created and taught to elucidate arts based on certain professional criterions.

In Pierre Felix Bourdieu's book Distinction, he discusses that the formal education, family, and social background mostly decided people's taste that can be used to distinguish different class. The interest and aesthetic dispositions are not inherent but acquired, and it is the sign of social distinction. Social class is a long-term historical construction, and it has the function of regulating and classifying the hierarchy. Aesthetic disposition is the production of social structural or normative action.

\section{FORMS OF SOCIAL EDUCATION IN MUSEUMS}

The national and Social Museum of the object of education is very different from the school education in the way of improving the comprehensive quality of the general public, it can educate everyone regardless of the age, sex, occupation and educational level of the visitors, and it can make every visitor an object of education, social Education and cultural industry as the main operating mechanism, so as to improve the overall quality of the general public ${ }^{[6]}$.

The openness and diversity of educational services museums usually use exhibitions to promote their culture, but not just exhibitions, museums need to constantly improve their own ways of publicity in accordance with the development of the times and the reality of the general public, to ensure that people can actively participate in museum-related activities, so as to achieve the goal of cultural publicity and education, if the museum cannot change its own mode of propaganda with the changes of the times, it will lead to the national lack of interest in the exhibition in the museum, even there will be a psychological aversion, it is difficult to achieve the goal of national quality education $^{[7]}$. As a result, museums need to constantly innovate their cultural propaganda models, move in the direction of people's interests, and keep them curious about the exhibits in museums, so as to attract more visitors, in order to ensure that visitors can be affected by the museum's fine culture, thereby improving the cultural quality of the public.

The visual and Inspiring Museum of Education is a collection, research, and display of historical value for all citizens to show the simulation of the real situation. The deeper the research on the scientific value of the collection, the deeper the educational value of the exhibits, and the more fully the educational function of the museum. It is not only the supplement but also the interpretation and extension of the textbook ${ }^{[8]}$.

\section{IMPROVE THE SOCIAL AND EDUCATIONAL FUNCTIONS OF MUSEUMS}

Integrate new technologies into exhibitions with the continuous development of the times, the exhibition methods of museums have also been greatly enhanced. In order to better satisfy people's aesthetic consciousness, in addition to the traditional ways of displaying pictures and words, museums display cultural relics, digital Technology, multimedia technology and other modern high-tech technologies should also be used for the exhibition of Cultural Relics. The application of modern high-tech technology can more accurately and comprehensively show the connotation contained in the cultural relics on display to visitors, and can better strengthen the exchange between visitors and the cultural relics on display. It continuously arouses the audience's curiosity and strong thirst for knowledge, and provides better conditions for the visitors to learn cultural knowledge. Museum exhibitions should give a full play to social life and natural history, so that people can better accept the edification of natural science knowledge and enrich people's spiritual life.

enhancement of the operational quality of Museum Staff Museum staff should, first of all, identify themselves as better service providers for visitors rather than supervising and managing visitors, we should establish "people-oriented" as the purpose of our work, 
and constantly improve the professional quality of museum staff. When visitors encounter difficulties and need help, museum staff should be patient, proactive and enthusiastic to provide timely help and services to visitors. Let visitors learn new knowledge in the harmonious atmosphere of the museum. Since the first person a visitor comes into contact with is the interpreter of the museum, the interpreter of the museum has become the main way for visitors to receive museum education. Museums should strengthen the training of the professional qualities of the interpreters, so that the interpreters in museums have strong professional knowledge and good language skills, it can better explain the characteristics, historical content and profound cultural connotation of the cultural relics displayed in the museum for visitors, and enable visitors to learn more knowledge in the museum. In addition, museum instructors should adopt different teaching methods according to different visitors to better attract, inspire and educate visitors.

expanding educational channels museums should expand educational channels to better display the social educational functions of museums. The following measures can be taken. ${ }^{[9]}$

1. Conducting lectures on museum topics. The museum conducts lectures on Special Topics and regularly disseminates patriotic education to the people, government organs, enterprises, institutions and schools, so as to give full play to the museum's function of social education and continuously improve people's quality.

2. Publish Popular Science Publications. Museums can publish popular science publications on Cultural Relics Collections to increase people's understanding of the cultural connotations of some cultural relics collections. In addition, the museum can put some Popular Science Knowledge of the exhibition culture in front of each exhibition stand and offer it to visitors free of charge. The diversified educational channels of museums can not only help visitors to understand the rich cultural connotation of the cultural relics on display in museums, but also make the social educational significance of museums better play ${ }^{[10]}$.

\section{OTHER CASES}

Other cases are the following piece that tells people:

In the book of Art as Experience, John Dewey thinks art is an ordinary experience that people have emotional resonance to beauty. Art work is the "enhancements" of that experience. When people communicate with environment (their daily life), experience is constantly being produced, so that it can almost be seen as the process of people's life. It is absorbed in people's mind, also be used to interact with environment for creating new experience. In order to adapt new surroundings, people need to transfer the existing experience to figure out current situation. The old experiences blend together with the present, so the new one arises. Art is a kind of unified and integrated experience which is an interactional product between people and environment. When people bring their senses and awareness into society for living and communicating, and based on convention to make integrated experience, these experiences could be regarded as a form of art, so that art relies on experience to be created.

If Barnes Foundation did not remove like now, it may be washed out from times, and the masters' works may not be saved well. Barnes is not a futurist, and he does not foresee the times' change which is irresistible. Jane K. Nielsen in his article "The relevant museum: defining relevance in musicological practices" explains that the shift for museum is necessary that being in a position to transform knowledge, research and communication to carry out its functions on educational, social, and entertainment needs that trying to adapt a wide variety of audiences.(Nielsen 372) When Barnes collection is turn into the new, modern space, something indefinable will be lost strictly, but more people can enjoy it than it has ever seen before. Barnes's collection is preserved that depends on the respect and appreciation in which held by a whole cultural value. If Barnes's collection is kept by the Lincoln or the former Foundation managers, they may make it become a commodity which is totally against Barnes's will.

The film "Art of the Steal" could do a deeper research of allowing public access to be defended, but gives people a cautionary tale whether today's Barnes Foundation fulfills its mission of original one that doing the better job on museum's education and other functions. Art culture, power and money have always played the role of cultural triplets in the world, at least the authorities and politicians are affording and protecting the art to the public. Even if they have "stolen" the art works from Barnes, they give it away to public. Lewis Hyde in his book The Gift mentions that art work is the artist's gift and only be exchanged that could be successful on realizing its value. The arts make other ancillary benefits which is valuable to society, like the economic development, but it is not the essential mission of the arts. Some people cannot recognize the influence and value of art to them, but the art still exist in and act on their world, not leaving. Same as gift, it is sent to others but does not require any return. Art can make sense without market economy, because its transmission relates on its inherent value rather than price. The art itself is meaningful to people's lift, but its power of influence, like transferring gift, is more important to people's spiritual world. The new Foundation as a public museum is the good and useful way to exploit the advantages to the full on transfer the 
value of Barnes and his collection. If Barnes could see that lots of people love his art so much, he would be delighted on his meaning about collecting these art works is doing on the great direction. Although Barnes's will was slowly demolished and written off, the times that led to write such a mean-spirited statement are gone with Barnes pass away and never appear for today ${ }^{[11]}$.

\section{CONCLUSION}

The basic social functions of museums are collection function, research function and social educational function. Among them, the social educational function of museums plays a very important role in the social functions of museums, once the Museum of social and educational function of the museum will lose the role of improving people's spiritual civilization. Therefore, the museum staff in their daily work, should continue to play and improve the museum's social education function to meet people's spiritual needs.

\section{REFERENCES}

[1] Barnes Foundation, https://www.barnesfoundation.org/about, Accessed 3 May, 2018

[2] Boorsma, Miranda \& Chiaravalloti, Francesco, "Arts Marketing Performance: An Artistic-Mission-Led Approach to Evaluation", The Journal of Arts Management, Law, and Society, vol.40, no.4, 2010, pp. 297-317

[3] Borwick, Doug. "Benefits of the Arts (Again)", Arts Journal,
[4] Bourdieu, Pierre. "Distinction: a Social Critique of the Judgement of Taste", Cambridge, Mass: Harvard University Press, 1984.

[5] Dewey, John. Art as Experience, 23rd Impression, G. P. Putuam's Sons, 200 Madison Avenue, New York, New York 10016

[6] Duncan, Carol, "Civilizing Rituals: Inside Public Art Museums", Padstow, Cornwall, T J International Ltd, 1995

[7] Hyde, Lewis. "The Gift-Creativity and the Artist in the Modern World", 25th Anniversary edition. Vintage, A Division of Random House, Inc. New York, 2007

[8] Levine, Lawrence W. "Highbrow/lowbrow: The Emergence of Cultural Hierarchy in America", Cambridge, Massachusetts. Harvard University Press. 1990

[9] McCall, Vikki \& Gray, Clive, "Museums and the 'new museology': theory, practice and organizational change", Museum Management and Curatorship, vol.29, no.1, 2013, pp. 19-35

[10] Nielsen, Jane K., "The relevant museum: defining relevance in musicological practices", Museum Management and Curatorship, vol.30, no.5, 2015, pp. 364-378

[11] Stuth, Tricia, "Continuity, Criticality, and Change", Journal of Architectural Education, vol.63, no.2, 2010, pp.112-127 